\title{
The Effect of Compensation, Organizational Commitment and Organizational Justice on Turnover Intention
}

\author{
${ }^{1}$ Dwi Sihono Raharjo, ${ }^{2 *}$ C. Catur Widayati and ${ }^{3}$ Rico P. \\ ${ }^{1}$ Faculty of Economics and Business, Universitas Persada Indonesia-YAI \\ Jakarta, Indonesia \\ email: dwisihono.raharjo@gmail.com \\ ${ }^{2,3}$ Faculty of Economics and Business, Universitas Mercu Buana, Jakarta, Indonesia \\ *Correspondence author: christine wijaya73@yahoo.co.id/catur.widayati@mercubuana.ac.id
}

\begin{abstract}
This research aims to test and analyze the effect of compensation, organizational commitment, and organizational fairness on outgoing wishes on employees in the company. The research method used in this study is descriptive method. The object of this research is a company engaged in property in Jakarta with a sample of 56 respondents. The approach used in this study is the Structural Equation Model (SEM PLS) with Smart-PLS analysis tools. The results showed that: (1) compensation has a negative and significant impact on turnover intention; (2) komitmen organization negative and significant impact on turnover intention and (3) eadiadiadi organization negative and significant to the desire to come out.
\end{abstract}

Keywords: Compensation, Organizational commitment, organizational fairness, outgoing desire.

DOI: $10.7176 / \mathrm{JRDM} / 81-05$

Publication date: December $31^{\text {st }} 2021$

\section{INTRODUCTION}

Human resources are the main pillars that serve as the cog in a company's activities to harness all its potential in an effort to achieve goals. The quality of human resources owned by a company will determine the success of the company in achieving its goals. Companies must spend a lot of money to obtain quality human resources. This is because the presence of quality human resources is an advantage that will increase the company's competitive ability (Wisyanto \& Madiistriyatno, 2015). The availability of quality human resources will largely depend on the extent of human resource management in the company. Companies that are aware of the importance of human resources for their survival will pay considerable attention to this aspect of human resource management.

According to Abdilah, (2012) turnover intention is a situation where workers have a conscious intention or tendency to find another job as an alternative in a different organization and turnover is the driver of the outflow of labor from where theywork. According to Widayati and Yunia (2016), one way that can be done in an effort to reduce the level of turnover intention is through compensation and good organization to achieve the expected performance in an organization or agency, employees must get adequate compensation and the development of a good organizational culture in order to reduce or even to prevent the occurrence of turnover intention in the company.

The company should pay special attention to employees by being fair as an award received for contributions to the company. To encourage employees to be loyal to the company, there must be appropriate reciprocity from the company, employees provide good work performance for the progress of the company, while the company provides compensation in accordance with the contributions of its employees. Compensation is very important for employees because the small amount of compensation affects the employee's intention to leave a company.

The cause of the magnitude of turnover intensity is also influenced by the low organizational commitment of the company's entrepreneurs. Organizational commitment as a degree to which employees believe and accept the goals of the organization and will remain or will notleave theorganization. If employees do not have organizational commitments then employees can leave the company at any time if the employee feels the company is not what they want.

Widjaja et al. (2011) revealed that the turnover process is characterized by a condition called turnover intention or employee intent to leave the company. Someone low-commitment to the company will look to withdraw from the company which will eventually give up on the employee's decision to leave the company. In the study Arijanto et al., (2020), An organization or company that experiences a high level of turnover intensity will have a negative impact on the organization if it leads to the decision of the employee to leave the organization (turnover) theref ore it is necessary to know the factors that can affect turnover intention so that the tendency for turnover can be emphasized.

The phenomenon in this study is the increase in turnover of a company engaged in property headquartered in Jakarta. Ideal human resource conditions are certainly expected by the company. 
Based on the turnover intention rate on employees at the property company from 2016-2018 is quite high and always increases every year. In 2016 there were 12 employees who entered and 14 employees who left. The increase in 2017 for incoming employees was 9 employees and the increase in outgoing employees was 17 employees. There was a very high increase in 2018 in employees who came out to reach 21 employees, a decrease in incoming employees to 7 employees. From year to year, 2016 to 2018 the property company always experienced a decrease in the number of employees. And lastly in 2019 employees decreased to 56 employees. This is a very serious problem for the company.

Turnover intention leads to the ultimate reality with the exit ofan employee at any givenmoment. Turnover intention can be resignation, exit of the company unit, dismissal, or death of a member of the company, the desire to leave an organization is generally preceded by employee intentions triggered, among others, by employee dissatisfaction with the job and low commitment of employees to bind themselves to the organization (Jimad, 2011).

Human resource management is not only limited to how to get quality human resources, but also no less important is how to maintain the existence of these human resources in order to still be able to contributeto the company. One of the problems that companies often face related to human resources is the existence of a high level of employee turnover. On the one hand, turnover is a good enough criterion to regulate stability and reflect the company's performance. Employee transfer is needed for companies in employees who have low work productivity (Yulisia, 2012).

Based on the results of pre-survey data obtained from 15 respondents obtained the results that in statement number 6 shows that the occurrence of employee dissatisfaction with compensation provided by the property company, so compensation is one of the causes of turnover intention. Statement number 8 indicates a low commitment to the organization, while the statement on number 9 indicates the low fairnessof theorganization, and statement number 10 indicates an indication of intention turnover. There are employees who leave the organization for a variety of reasons. The reason for the selection of the company is because of the discovery of indications of a desire to stop for various reasons, namely career, family and work atmosphere.

Many studies examine the factors that influence turnover intentions, including compensation. Zakaria and Astuty, (2017) conducted a study with research results based on the analysis that has been done obtained results that compensation has a negative and significant effect on turnover intention. Research on organizational commitment by Witasari, (2009) with the results of his research shows that partially organizational commitment positively affects turnover intention. Basri, (2012) Tests fairness in organizations against the desire to switch public accountants. His research showed that perceptions of justice influence intentions to move.

Based on the phenomenon and background above, the problems that arise are as follows: (1) Does compensation affect turnover intentions on employees in property companies in Jakarta?; (2) Does the organization's commitment affectturnover intentions in employees at property companies in Jakarta?; (3) Does organizational fairness affect turnover intentions in employees at property companies in Jakarta?

While the purposeof this research is: (1) Uto know and analyze the effect of compensationon turnover intentions on employees in property companies in Jakarta.; (2) To know and analyze the influence of organizational commitment to turnover intention on employees in property companies in Jakarta.; (3) To find out and analyze the effect of organizational fairness on turnover intentions on employees of PT. Image of the Magnificent Tower.

\section{THEORETICAL REVIEW}

\section{Employee Exit Wish (Turnover Intention)}

Desire (Intention) itself is interpreted as an intention that arises in individuals to do something whil turnover according to Wirawan, (2015) Moving work (turnover)is anemployee quits a company or organization and moves work tothe company for certainreasons. According to Wirawan, (2015) turnover intention is the tendency or intention of employees to stop working from their jobs voluntarily according to their own choice. According to Abdullah et al.,(Yudaand Ardana, 2017) turnover intention is a situation where workers have intentions or tendencies that are done consciously to find other jobs as an alternative in different organizations, the desire to move can be used as an early symptom of turnover in a company. The definition of severe experts regarding turnover intention can be summed up as a situation that occurs in any individual employee having a desire to exit an organization or company to move to another organization or company.

\section{Compensation}

According to Dessler, (2013) stated that compensation refers to all forms of pay or rewards for employees derived from theirwork. According to Kadarisman, (2014) suggests compensation is a function of Human Resource Management that deals with each type of reward that individuals receive in return for the work of organizational tasks. Stewart and Brown, (2011) definecompensation asthe process of paying and rewarding people for the contributionsmade to an organization. According to Hasibuan, (2013) compensation is all income 
in the form of money, direct or indirect goods received by employees in return for being given to the company. The definition of experts can be concluded that compensation is an income that must be earned by each employee in return given by the company.

\section{Organizational Commitment}

George and Jones, (2012) state that organizational commitment is the feeling and trust about how a person works within the organization. The willingness of individuals to become members of the organization both in a state of joy and forced, for example because there is no other choice, is a bagian of the understanding of the organization. According to Darmawan (Sianipar and Haryanti, 2014) explained that commitment means the desire of employees to maintain their membership in the organization and be willing to make high efforts to achieve organizational goals.

Menurut Mathhis and Jackson (Nurandini, 2014) organizational commitment is the level to which employees are confident and accept the organization's goals and want to stay with the organization. Thus, it can be concluded that organizational commitment is a trust, a belief felt by every employee to survive in one organization or company.

\section{Organizational Justice}

According to Wiratama and Suana, (2015) organizational justice is a treatment, as well as actions received by every employee equal regardless of position status or position and can be said to be fair if employees get their rights in accordance with what they contribute to the company. Kristanto, (2015) defines organizational fairness as a degree at which an individual feels the same need in the organization in which he or she works.

According to Hwei and Santosa, (2012) said that organizational justice assessments have an impact on employee attitudes and reactions, when employees are treated fairly, they will have the attitudes and behaviors needed for successful organizational change even in difficult conditions. According to Griffin andMoorhead, (2010) organizational justice is an important phenomenon that has recently been introducedinto organizational studies. Justice can be discussed from a variety of perspectives, including motivation, leadership, and group dynamics. The definition of a severe expert can be concluded that organizational fairness is an act or behavior of an organization that is given to every employee fairly without any perceived gaps by employees.

\section{Hypothesis Development}

\section{Effect of Compensation on Turnover Intention}

Research conducted by ZakAria and Astuty, (2017) stated that the results obtained are a negative and significant relationship between compensation against turnover intention. While the research conducted Sasmita et al., (2017) states that the results obtained are a negative and significant relationship to turnover intention. Based on the above statement, a hypothesis can be drawn as follows:

H1: Compensation for Negative Impact on Turnover Intention

\section{The Effect of Organizational Commitment on Turnover Intention}

Research conducted by Widyadmono, (2015) stated that the results obtained are a significant negative relationship between job satisfaction and organizational commitment to turnover intention. Research conducted by Kharismawati and Dewi, (2016) states that the results obtained are a significant negative relationship between organizational commitment, social support, and the ethical climate against turnover intention. Based on the above statement, it can be drawn asa hypothesis asfollows:

H2: Organizational Commitment berpengaruh negativethahadap Turnover Intention

\section{The Effect of Organizational Justice on Turnover Intention}

Research conducted by Yunita and Putra, (2015) shows that organizational justice and work environment negatively and significantly affect turnover intention. While research conducted by Arif, (2018) shows that organizational fairness has a negative and significant effect on turnover intention. Based on the above statement, a hypothesis can be drawn as follows:

H3: Organizational Justice berpengaruh negatif terhadap Turnover Intention

\section{RESEARCH METHODS}

This research process begins with the activity of identifying problems at the time and place to be used as research sites, formulation of identified problems, the collection of theoretical bases that strengthen the foundation in variables, the preparation of methods in data collection, to the determination of istic static testing techniquesused. This study takes the period March 2020 - August 2020. The object of the research is a Property Company located in Jakarta. 
The research designused by the authors is causal research design using a quantitative analysis approach. Causal research is defined as a causal relationship, in which independent variables affect dependent variables (Sugiyono, 2013). This research was conducted to find out the influence of three variables, namely compensation, organizational commitment and organizational fairness to dependent variables, namely turnover intention in Property Companies in Jakarta.

In this study, the population was employees of Property Companies in Jakarta which amounted to 56 employees. According to Sugiyono, (2017) The sample is part of the number and characteristics that the population has. If the population is large and researchers are unlikely to study everything in the population, for example due to limited funds, energy and time, then the researcher can use samples taken from that population. What is learned from that sample, the conclusions will be applicable to the population. For this reason, samples taken from the population must be representative.

Sampling technique itself there are two types, namely probability sampling and non probability sampling. Probability sampling is a sampling technique that provides an equal opportunity for each element (member) of a population to be selected into a sample member. Nonprobability sampling is a sampling technique that does not provide equal opportunities or opportunities for every element or member of the population to be selected into a sample (Sugiyono, 2017). This study uses nonprobability sampling, where the sampling to be used is saturated sampling (census),so that for the sample used as many as 56 respondents.

\section{RESULTS AND DISCUSSIONS}

Structural Model Testing or Hypothesis Test(Inner Model)

Inner model testing is the development of concept-based models and theories in order to analyze the relationships between exogenous and endogenous variables that have been spelled out in conceptual prejudice.

a. R-square Value Test Results

Look at the R-square value which is the model's goodness-fittest.

Table 1. $\mathrm{R}^{2}$ Endogenous Variable Values

\begin{tabular}{lc}
\hline Endogenous variables & R-square \\
\hline Turnover Intention & 0.773 \\
\hline
\end{tabular}

Source: PLS Output, 2020

Structural models indicate that the model on the turnover intention variable can be said to be strong because it has a value above 0.67 . The independent latent variable influence model(compensation, organizational commitment, and organizational fairness)on turnover intentions provides an R-square value of 0.773 that can be interpreted that the variability of the turnover intention construct that can be explained by the variability of the compensation construct, the organization's commitment $77.3 \%$ of the organization's fairness was explained by other variables beyond those studied.

\section{b. Goodness of Fit Model Test Results}

The structural model's Goodness of Fit test on the inner model uses predictive-relevance values (). $Q^{2}$ A Q-square value greater than 0 (zero) indicates that the model has a predictive relevancevalue. The R-square value of each endogenous variable in this study can be seen in the following calculations:

Predictive relevance values are obtained by the formula:

$Q^{2}=1-(1-R 1)\left(1-R_{p}\right)$

$Q^{2}=1-(1-0.7730)$

$Q^{2}=1-(0.2270)$

$Q^{2}=0.7730$

The calculation above shows a predictive-relevance value of 0.7730 which is greater than 0 (zero). That means that $77.30 \%$ of turnover intentions are explained by the independent variables used. Thus the model is said to deserve to have relevant predictive value.

c. Hypothesis Testing Results (Estimated Path Coefficient)

The estimated value for path relationships in structural models should be significant. The value of significance on this hypothesis can be obtained by the boostrappingprocedure. Look at the significance of the hypothesis by looking at the parameter coefficient value and the T-statistical significance value on the algorithm 
boostrapping report. To know the significant or insignificant seen from the T-table at alpha $0.05(5 \%)=1.96$, then T-table compared to T-calculate (T-statistics).

Table 2. Hypothesis Testing Results

\begin{tabular}{lccccc}
\hline & $\begin{array}{c}\text { Original } \\
\text { Sample }\end{array}$ & $\begin{array}{c}\text { Standard } \\
\text { Deviation }\end{array}$ & $\begin{array}{c}T- \\
\text { Statistics }\end{array}$ & $\begin{array}{c}P \\
\text { Values }\end{array}$ & Information \\
\hline $\begin{array}{l}\rightarrow \text { Turnover } \\
\begin{array}{l}\text { Intention } \\
\text { Compensation }\end{array}\end{array}$ & -0.780 & 0.198 & 3.928 & 0.000 & Negative -Significant \\
$\begin{array}{l}\text { Organizational } \\
\text { Commitment } \rightarrow\end{array}$ & -0.236 & 0.099 & 2.375 & 0.001 & Negative -Significant \\
$\begin{array}{l}\text { Turnover Intention } \\
\text { Organizational }\end{array}$ & -0.354 & 0.128 & 2.732 & 0.000 & Negative -Significant \\
$\begin{array}{l}\text { Justice } \rightarrow \text { Turnover } \\
\text { Intention }\end{array}$ & & & & & \\
\hline $\begin{array}{l}\text { Source: PLS Output, 2020 } \\
\text { Sourtiont }\end{array}$ & & & & &
\end{tabular}

\section{Discussion of Research Results}

\section{Effect of Compensation on Turnover Intention}

Based on the hypothesis test in this study obtained the results of T-statistics of 3,928, original sample values of -0.780 , and $P$ Values of 0.000 . The T-statistic is greater than the T-table value of 1.96 , the original sample value indicates a negative value, and at the value of $\mathrm{P}$ Values showing less than 0.05 , these results indicate that compensation has a negative and significant effect on turnover intention. From the results of boostraping has the most dominant value of $(16,156)$ in the statement "Iget a salary or upah in accordance with applicable UMR standards".

Turnover intention can be interpreted as the employee's intention to move from an organization or leave the organization, either in the form of dismissal or resignation. There are many factors that affect an employee's desire to leave the organization, one of which is compensation. From the results of research that has been done, it can be known that the compensation variable (X1) has a significant effect on turnover intention (Y1). This shows that compensation (X1) contributes greatly in lowering turnover intention (Y1). Compensation that is the employee's right will be evaluated by the employee in many aspects. When they feel compensation in accordance with the workload provided, as well as compensation provided in accordance with the promised level of compensation, the employee will feel the satisfaction of compensation and will have no desire to leave the organization. With the working period component, the longer the employee's working life should be the greater the compensation received by employees. In addition, companies also need to provide attractive bonuses, where bonuses can be used to reward employees for contributing new ideas, developing their skills, or getting professional certification. So the company must pay attention to these things so that employees get compensation satisfaction. Dissatisfaction with compensation will trigger negative employee behavior such as arrogance and lethargy. Often grouped in resignation behavior or also referred to as the desire to stop working. If employees are not satisfied with the compensation provided by the company, then employees will behave negatively and will increase turnover intentions. This can be concluded if a company's compensation system is getting better it will reduce the desire of employees to leave.

This research is supported by Siska S. research, Tetra H. (2017) which found that compensation has a negative and significant effect on turnover intention. As well as research conducted by Royan Z. \&Astuty I. (2017) where compensation has a negative and significant effect on turnover intentions in employees.

\section{The Effect of Organizational Commitment on Turnover Intention}

Based on the hypothesis test in this study obtained the results of T-statistics of 2,375, original sample values of -0.236 , and $P$ Values of 0.001 . The T-statistic is greater than the T-table value of 1.96 , the original sample value indicates a negative value, and at the $\mathrm{P}$ Values value showing less than 0.05 , these results indicate that the organization's commitment negatively and significantly affects turnoverintentions. Boostraping results have a dominant value of $(21,429)$ with the statement "Iam very sorry if I leave this company.

Based on the results of this study, the commitment of property company employees in Jakarta has a high level of commitment with an average score of 4.00 on a scale of 5 . This high commitment is characterized by indicators of employee comfort in the company, a sense of family built in the company, having an attachment to 
the company, being loyal to the company, worrying about if bad things happen in the company, the pleasure of being an employee in the company, feeling the positive values of the company, feeling the company becomes meaningful and various other indicators. Organizational commitment is identified as how far an employee identifies with the organization and his or her involvement in a particular organization is critical in lowering employee turnover intentions. Employee commitment that is shown positively will reduce the employee's intention to quit the company. Based on the average value of the variable turnover intentionindicator, the level of intention out of the company is quite low. The employee's intention or plan to leave the company in the near future is at a low value. While the activities of employees in finding new job opportunities are at sufficient value. So it is concluded, with the increase in the organization's commitment to employees to the company where they work, it will reduce the employee's intention to leave(turnover) of the company.

The results of this study support research conducted by Mardi, V. W. (2015) which explains that organizational commitment negatively affects turnover intention. Dewa, A. \& Gusti, A. (2016) in the results of the study showed that organizational commitment negatively affects turnover intentions in employees.

\section{The Effect of Organizational Justice on Turnover Intention}

Based on hypothesis tests in this study obtained the results of T-statistical values of 2,732, original sample values of -0.354 , and $P$ Values of 0.000 . The T-statistic is greater than the T-table value of 1.96 , the original sample value indicates a negative value, and at the value of $\mathrm{P}$ Values showing less than 0.05 , these results indicate that organizational fairness negatively and significantly affects turnover intentions. Based on the results of boostraping has the most dominant value of $(25,624)$ in the statement "Ifeel the procedures used by the company to determine the raise arefair".

The results of this study indicate that the lower the fairness in the organization, the higher the desire of employees to move or leave the organization. Organizational justice is a treatment, as well as actions received by every employee equally regardless of position status or position and can be said to be fair if employees get their rights in accordance with what they contribute to the company. If every employee gets equitable organizational fairness, there is no difference between employees with other employees then the employee does not think about doing turnover intention. But if employees who feel the award is not given fairly may be motivated to pursue employment in another possibly fairer organization that will honor the individual and reward the organization accordingly. Imbalances in perceptions of fairness can cause an employee to feel as if they are being treated unfairly. Ultimately a low perception of organizational fairness can cause employees to have thoughts of leaving the organization. This influence has the meaning that the higher the level of organizational fairness received by employees, the lower the level of desire out of employees.

The results of this study are in accordance with the results of research conducted by Saraswati, S. (2018) which found that organizational fairness negatively and significantly affects turnover intention. In addition, it also supports the results of research Ihsan, D. \& Syahrizal (2019) which states that organizational justice has a negative and significant effect on the intention of exiting karywan.

\section{CONCLUSION}

1) Compensation has a significant negative effect on turnover intentions in employees of Property Companies in Jakarta. This means that the better the compensation provided by the company, the turnover intention of employees will also decrease.

2) The commitment of the organization has a significant negative effect on turnover intentions in employees of Property Companies in Jakarta. This means that if the organization increases the commitment of the organization to the company where they work, it will decrease the employee's intention to leave the company.

3) Organizational fairness has a significant negative effect on turnover intentions in employees of Property Companies in Jakarta. This means that the higher the level of organizational fairness received by employees, the lower the level of desire out of employees.

\section{Suggestion}

1) The company is expected to provide a workload that is in accordance with the compensation promised to the employees. In addition, the company also needs to provide attractive bonuses, where the bonus can be used to reward employees so that they will feel the satisfaction of compensation and will have no desire to leave the organization.

2) To the company is expected to better maintain the emotional bond of the employees so that they feel attachment to the company. By focusing more on the commitment together between employees with employees and between leaders and subordinates. 
3) To the company is expected to make a fair contribution in determining the salary increase of employees. In addition, the company is expected to re-develop existing procedures in determining the promotion of fairer promotions among its employees.

4) To the company should provide a job that attracts employee morale, so that employees feel comfortable and do not look for work outside the company.

Advice for future researchers, who will conduct research in the same field and use this thesis as a reference, then it should be reviewed because it does not rule out the possibility of statements that are not appropriate, because I as a writer feel there are still many shortcomings and limitations in completing this thesis. In addition, researchers can then use other variables such as employeeengagement, burnout, organizational citizenship behavior, and so on to develop research.

\section{REFERENCES}

Abdillah, Fuad. (2012). Kohevitas Group Relationship With Turnover Intentions in Employees. Journal of Social and Industrial Psychology. 1(2), 52-58.

Anoki, Herdian, Dito. (2010). Effect of Compensation on Employee Performance of PT. Slamet Abadi Purbalingga With Work Motivation as An Intervening Variable. Thesis Bachelor Program Faculty of Economics, Diponegoro University, Semarang.

Ardana, I Komang. (2012). Human Resource Management. Yogyakarta: Graha Ilmu.

Arijanto, A., Marlita, D., Suroso, A., \& Purnomo, R. (2020, February). How is the Effect of Job Insecurity, Work Stress, and the Work Environment on Turnover Intention: A Case Study at the Company of Supplier Security System in Indonesia. In 4th International Conference on Management, Economics and Business (ICMEB 2019) (pp. 114-119). Atlantis Press.

Cahayu, Asri Putu, and Adnyani, Ayu Gusti. (2015). Effect of Organizational Justice on Job Satisfaction and Organizational Citizenship of Nyoman Store Employees. E-Journal of Management Unud. 4(11), 37463747.

Cut Zurnali. (2010). Learning Organization, Competency, Organizational, Commitment, and People in the Future. Publisher of Unpad Press, Bandung.

Dessler, Gary. (2010). Human Resource Management. Jakarta: PT. Index.

Dessler, Gary. (2013). Human Resource Management Thirteenth Edition, New Jersey. Publisher Prentice Hall.

George, M.J. and Jones, R. G. (2012). Understanding and Managing Organizational Behavior. 6th Edition. Prentice Hall. New Jersey.

Ghozali, Imam and Latan, Hengky. (2015). Partial Least Squares, Concepts, Techniques and Applications Using the Smartpls 3.0 Program for Empirical Research Concepts. Edition 2, Semarang: Diponegoro University Publishing Body

Griffin and Moorhead. (2010). Organizational Behaviori Managing People and Organizational Ninth Edition South-Westren Cancage Learning.

Hwei She, Santosa Elisabeth Cintya. (2012). Influence of Procedural Justice and Distributive Justice on Organizational Commitment. Journal of Economic and Business Dynamics. 9(2), 41-42.

Ihsan, Dani., Shahrizal., and Fitria, Yuki. (2019). The Effect of Organizational Justice On Exit Intentions on Employees with Job Satisfaction as a Mediation Variable. Journal of Management and Entrepreneurial Studies, 1 (1), 36-45.

Jimad, Habibullah. (2011). Job Satisfaction, Organizational Commitment, and Turnover Intention, Journal of Business \& Management, Journal of Management Department of the Faculty of Economics, University of Lampung, Bandar Lampung, 7(2), 155-163.

Kaswan. (2012). Human Resource Management for Organizational Competitive Advantage. First edition. Yogyakarta: Graha Ilmu.

Kharismawati, Dewa Ayu Putu., andDewi, I Gusti Ayu Manuati. (2016). Influence of Organizational Commitment, Social Support, and Ethical Climate On Turnover Intention. E-Journal of Management Unud, 5 (2), 1368 - 1398. ISSN: 2302-8912.

Kristanto, Harris. (2015). Organizational Justice, Organizational Commitment and Employee Performance. Journal of Management and Entrepreneurship. 17(1), 87-88.

M. Kadarisman. (2014). Compensation Management, Jakarta: PT. King Grafindo Persada.

Mangkunegara, Anwar Prabu. (2016). Corporate Human Resource Management. Eleventh Print. Teenager Rosdakarya. Bandung.

Nandini, Nurhasmadiar and Thinni Nurul, Rocmah. (2013). Causes of Turnover Intention in Nutrition Installation Employees of PHC Surabaya Hospital. Journal of Indonesian Health Administration. 1(3), 272-279.

Nurandini, A. (2014). Analysis of The Influence of Organizational Commitment on Employee Performance (Study on Employees perum Perumnas Jakarta). Thesis published by Faculty of Economics and Business, Diponegoro University. Semarang. 
Purna, I Nyoman. (2013). Job Satisfaction and Organizational Commitment: Its Effect on Exit Intentions, EJournal of Economics and Business Udayana University, 2 (12).

Pangestu, A.A. (20 14). Impact of Work and Organizational Commitment on Employee Performance (Study on BNI KCU Semarang). Thesis published by Faculty of Economics and Business, Diponegoro University. Semarang.

Widayati, C., \& Yunia, Y. (2016). Effect of Compensation and Organizational Culture on Turnover Intention. Journal of Management, 20(3), 375-388. 